\title{
Classroom Culture and Its Impact on English Language Teaching
}

\author{
Ali Ahmed Hussein \\ Qatar University, Doha, Qatar
}

\begin{abstract}
This paper investigated the topic classroom culture and its impact on English language teaching (ELT). The paper consists of two parts. Part one deals with the definitions of culture in general and classroom culture in particular with reference to the literature in the field and some relevant internet websites. It also covers other issues that include establishing classroom culture, characteristics of effective classroom culture based on Wojcicki who listed about seven salient characteristics. This part also discusses the factors that influence classroom culture. These factors include teacher-student relationship, attendance and punctuality, interruptions, seating, and participation in class. Part two, on the other hand, focuses on the impact of classroom culture on ELT methodologies and materials. Moreover, some suggestions are offered to teachers on how to create a sense of cultural awareness in their teaching context, as cultural awareness is considered a key to success in ELT.
\end{abstract}

Keywords: culture, classroom, ELT, impact, teaching culture, cultural awareness

\section{Introduction}

At the outset of this study, it is important to distinguish between culture in general and classroom culture in particular, which is the focus of this paper. In general, culture is a broad concept that embraces all aspects of human life, such as knowledge, art, traditions, history, religion, customs, norms, and values. In an attempt to understand culture in general, many definitions have been given. For example, Brown (1994, p. 170, as cited in Çakir, 2006, p. 2) stated that,

Culture is deeply ingrained part of the very fiber of our being, but language- the means for communication among members of a culture -is the most visible and available expression of that culture. And so, a person's world view, self-identity, and systems of thinking, acting, feeling, and communicating can be disrupted by a change from one culture to another.

Çakir (2006, p. 2) summed up the definition of culture, when he said,

In a word, culture is a way of life (Brown, 1994, p. 163). It is the context within which we exist, think, feel, and relate to others. It is the "glue" that binds a group of people together. It can be defined as a blueprint that guides the behavior of people in community and is incubated in family life. It governs our behavior in groups, makes us sensitive to matters of status, and helps us to know what others expect of us, and what will happen if we do not live up to their expectations. Thus, culture helps us to know how far we can go as individuals and what our responsibility is to the group.

One more definition of culture is the following website definition, "Culture can be viewed as the customs, arts, and social interactions of a particular nation, people, or other social group. It can also be defined as an

Ali Ahmed Hussein, Ph.D., lecturer, Department of English, Foundation Program, Qatar University. 
appreciation of the arts and human intellectual achievement."

For all the views of culture cited in the quotations above, the following examples can provide good support for more understanding of culture.

\section{Popular Culture}

The activities of the citizens generate the popular culture. What you listen to, read, and wear, and how you speak are all examples of your popular culture.

According to the Wikipedia, "popular culture" was coined in the 19th century or earlier. Traditionally, popular culture was associated with poor education and the lower classes as opposed to the "official culture" and higher education of the upper classes. The stress in the distinction from "official culture" became more pronounced towards the end of the 19th century, and a usage of popular culture became established by the period.

Moreover, in the Wikipedia, the developments and cultural changes that followed World War II are briefly stated as follows:

From the end of World War II, following major cultural and social changes brought by mass media innovations, the meaning of popular culture began to overlap with those of mass culture, media culture, image culture, consumer culture, and culture for mass consumption. Social and cultural changes in the United States were a pioneer in this with respect to other western countries. ${ }^{2}$

\section{Foreign Culture}

You might visit a new country and feel surprised at the way in which people in that country talk, think, or act. The language of a country binds together the citizens of a country and can allow for their effective communication. Dialects and accents can help identify the various subcultures within a country.

\section{Corporate Culture}

Culture at work can be shown in a variety of ways including how people dress, how the offices are designed, how the employees are treated, and how company shows its culture into its products and services and how it projects itself to its customers. A website defines corporate culture as:

The beliefs and behaviors that determine how a company's employees and management interact and handle outside business transactions. Often, corporate culture is implied, not expressly defined, and develops organically over time from the cumulative traits of the people the company hires. A company's culture will be reflected in its dress code, business hours, office setup, employee benefits, turnover, hiring decisions, treatment of clients, client satisfaction, and every other aspect of operations. ${ }^{3}$

\section{Classroom Culture}

Classroom culture and English language teaching (ELT) are closely related and in this regard, Tang (1999, as cited in Çakir, 2006, p. 2) stated that "culture is language and language is culture."

He suggested that,

To speak a language well, one has to be able to think in that language, and thought is extremely powerful. Language is the soul of the country and people who speak it. Language and culture are inextricably linked, and as such we might think about moving away from questions about the inclusion or exclusion of culture in foreign language (FL) curriculum, to issues of deliberate immersion versus non-deliberate exposure to it.

\footnotetext{
${ }^{1}$ Retrieved from http://examples.yourdictionary.com/examples-of-culture.html.

2 Retrieved from http://examples.yourdictionary.com/examples-of-culture.html\#IvFmDscI9IzrDxxT.99.

${ }^{3}$ Retrieved from http://www.investopedia.com/terms/c/corporate-culture.asp.
} 
Regarding classroom culture, which is the focus of this study, and in the context of FL learning, it can be defined as, “...The often unspoken and frequently unconscious assumptions about how people (both the teacher and the students) will behave during the lessons-Where will people sit or stand? Who will speak, when, and what about? What types of behavior are appreciated, tolerated, or frowned upon?”4

Actually, there is no right or wrong answer as to what is the best definition for classroom culture. This is because there are classroom cultures that are conducive to learning, and others that are clearly not. "A learner's culture plays a vital role in determining acceptance or rejection of learning a FL” (Mahmoud, 2013, as cited in Mahmoud, 2015, p. 66).

\section{Establishing Classroom Culture}

At the beginning of a new academic year or semester, teachers, whether novice or experienced, usually have different feelings when they meet new students for the first time. They may feel nervous, curious, excited, normal, confused, etc.. Now, the question is how can ELT teachers establish classroom culture that promotes teaching and learning? To answer this question, a teacher should have a clear view of what type of culture she/he wants to create. However, effective learning may occur in classrooms where the teacher has a highly authoritarian role and learners "speak when spoken to and do what they are told to do." Learning that is more effective can also occur in "democratic" classrooms, where students are encouraged to take full responsibilities for their own learning. An example of establishing classroom culture is called the "Four Tribes Agreement," which includes:

(a) attentive listening;

(b) appreciation and no put-downs;

(c) right to pass and participate;

(d) mutual respect.

\section{Characteristics of Effective Classroom Culture}

Wojcicki (2002) listed the following items that characterize effective classroom culture:

1. All share the control in the classroom;

2. The teacher needs to work both as a facilitator and teacher;

3. The teacher must believe in the student's ability to achieve;

4. The curriculum must be relevant to real life;

5. The teacher should model the behavior;

6. The teacher should exhibit passion for the subject or teaching or both;

7. Teacher must be seen by students as fair, knowledgeable, unbiased, willing to help, and easily approached.

We think each of the above items is extremely important in contributing to classroom culture and making it effective, in the sense that it facilitates learning and enhances students' engagement.

\section{Factors that Influence Classroom Culture}

Classroom culture can be influenced by a number of factors, which can be listed as follows.

\footnotetext{
${ }^{4}$ Retrieved from http://eltnotebook.blogspot.qa/2006/09/first-lessons-establishing-classroom.html.

${ }^{5}$ Retrieved from http://www.teachingchannel.org/videos/positive-class-culture-nea.
} 


\section{Teacher-Student Image/Relationship}

This factor includes the differences between the teacher and students in terms of status, age, culture, gender etc. The teacher and students may have the same or different views of their various roles and responsibilities. Related to this factor is the relationship between the students themselves and the images they have about each other. Another influence on classroom culture comes from the image that students have about their teacher and what kind of relationship they have with their teacher. One more factor that affects classroom culture is the use of students' own language in the classroom and for what purpose.

\section{The Setting of the Lesson}

This factor includes the room suitability in terms of size, attractiveness, and whether or not it has sufficient facilities, such as the Overhead Projector (OHP) as well as other equipment. Moreover, are the seats movable or fixed? Movable seats allow for group activities and more interaction between learners.

\section{Attendance and Punctuality}

Under this factor, the following issues need to be taken into consideration, as they directly affect classroom culture:

1. Are students expected to attend every lesson?

2. Does the teacher wait for late comers?

3. Do late comers explain why or just come in and sit in silence?

4. Absence rate: high or low? And why?

\section{Seating}

The way students are seated in the classroom is another factor that can have direct impact on classroom culture. It includes the following issues:

1. Where do students sit?

2. Do they choose their own places, or does the teacher decide?

3. Do they sit in rows? In groups? Or U-shape?

4. Do students stay in the same seat for the whole lesson or move around?

5. Does the teacher sit or stand?

\section{Interruptions}

Are the students encouraged to interrupt the teacher/each other with questions and/or comments? If they are not encouraged to do so, then how and when can the teacher check that they have fully understood or answered their questions?

\section{Participation in Class}

Undoubtedly, students' participation in class can also be influenced positively or negatively by classroom culture. So many issues can be discussed under these factors, such as whether the students are encouraged to participate in class, and whether they all participate or just a few of them. If some do not participate in class at all, there may be culture-related factors that inhibit them from doing so.

\section{The Impact of Classroom Culture on ELT Methodologies and Materials}

This is the second and important part of the study to see in what ways classroom culture impacts ELT. It is clear from the above discussion that paying more attention to the place and the role that culture would play in 
writing and designing EFL textbooks is extremely important (Mahmoud, 2015, p. 1). In other words, classroom culture affects the selection of teaching materials from different sources, methodologies, and teaching styles, which should be flexible and adaptable to students' culture. And above all, classroom culture has direct impact on students' motivation and engagement. Çakir (2006, p. 4) suggested a good idea in which classroom culture can play a vital role:

The use of role-play in EFL classrooms can help students to overcome cultural "fatigue," and it promotes the process of cross-cultural dialogues, while, at the same time, it provides opportunities for oral communication. Numerous other techniques - readings, films, simulation, games, culture assimilators, culture capsules and culturagrams can be used for language teacher to assist them in the process of acculturation in the classroom. (Chastain, 1988)

The same author also suggested that the excessive use of culture-based activities in the classroom helped learners be familiar with the target culture and that the activities in the materials should involve the cultural values of the target language designed for every level. Classroom cultural activities usually may cover the daily life of the peer group in the other language community - their families, their living conditions, their school, their relations with their friends, their leisure-time activities, the festivals they celebrate, the ceremonies they go through, as well as their marriages and mourning customs.

Although learners benefit a lot from the cultural component in language learning, yet the impact of classroom culture on language teaching may not always be positive. Some learners who belong to cultures that differ from the culture of the majority of students in the classroom may experience inhibiting effects of cultural barriers in the classroom, and thus feel a sense of alienation, which may have a negative effect on their learning a FL. In teaching a FL, we need to be aware of cultural differences between students, and hence adopt teaching techniques and styles that promote cultural understanding and that eventually lead to better learning of a FL.

\section{Conclusions}

Thus far, recognizing the importance of classroom culture in ELT is of immense significance. As a result, it becomes clear that teachers need to develop a sense of cultural awareness in the context of their teaching. There are different suggestions to do this, such as to seek to understand the identity, culture, and language of each student and build connections with them. Another suggestion is to support students to develop their own learner profiles. Teachers can also use their knowledge about each student to plan effective teaching and learning and more importantly to include students' languages and cultures in classroom practice and lesson. Both learners and teachers of a second language should understand cultural differences and recognize that everyone in the world has his/her own identity. As such, language teachers cannot avoid conveying impressions of another culture, whether they realize it or not (Rivers, 1981, p. 315). Language is deeply embedded in culture, and therefore, cannot be separated completely from it.

Here, Çakir (2006, p. 5) suggested a good way of establishing cultural awareness as follows:

While developing cultural awareness in the EFL classroom, it should be kept in mind that the native language is learned along with the ways and attitudes of the social group, and these ways and attitudes find expression through the social group. Learning to understand a foreign culture should help students of another language to use words and expressions more skillfully and authentically; to understand levels of language and situationally appropriate; to act naturally with persons of the other culture, while recognizing and accepting their different reactions; and to help speakers of other tongues feel at home in the students' own culture. 
Seelye (1968, as cited as Rivers, 1981, pp. 323-324) suggested some of the benefits of cultural awareness that, "Students should be able to demonstrate that they have acquired certain understandings, abilities, and attitudes," and gave the following examples to support that:

1. Students understand that people act the way they do, because they are using options that the society allows for satisfying basic physical and psychological needs;

2. They understand that social variables, such as age, sex, social class, and place of residence, which affect the way people speak and behave;

3. They can demonstrate how people conventionally act in the most common mundane and crisis situations in the target culture;

4. They are aware that culturally conditioned images are associated with even the most common target words and phrases;

5. They are able to evaluate the relative strength of a generality concerning the target culture in terms of the amount of evidence substantiating the statement;

6. They have developed the skills needed to locate and organize material about the target culture from the library, mass media, and personal observation;

7. They possess intellectual curiosity about the target culture and empathy toward its people.

Moreover, Steelye (1968) suggested that teachers can help learners move through stages of acculturation. If learners are aided in this process by sensitive and perceptive teachers, they can perhaps more smoothly pass through the second stage and into the third stage of culture learning, and thereby, increase their chances for succeeding in both second language learning and second culture learning.

It has been suggested by many authors (Çakir, 2006; Hiep, 2007) that there is an issue to be focused upon and that before learning about culture, students must be prepared to the concept of learning about other cultures than their own. In this respect, a teacher must play a vital role. First to raise students' awareness that there are cultures that differ from theirs and the teacher also has to play a role in creating an atmosphere free of cultural barriers prior to teaching-learning activities. One way to begin teaching culture in a positive way is to focus on similarities between learners' cultures, in order to create a sense of unity between learners, which eventually will set the scene for a positive learning environment. Moreover, the topics used to teach the target language should be culturally appropriate to all learners. Çakir (2006) suggested that “... while teaching a culture specific topic, first language equivalent can also be given in order to enhance learning” and then concluded that,

The aim is to increase students' awareness and to develop their curiosity towards the target culture and their own, helping them to make comparisons among cultures. The comparisons are not meant to underestimate any of the cultures being analyzed, but to enrich students' experience and to make them aware that, although some culture elements are being globalized, there is still diversity among cultures. This diversity should then be understood, and never underestimated. (Çakir, 2006, p. 6)

It is now clear that classroom culture and language teaching are almost inseparable and that creating a sense of cultural awareness among teachers and learners will definitely enhance and facilitate language learning. 


\section{References}

Brown, H. D. (1994). Principles of language learning and teaching. Englewood Cliffs, N.J.: Prentice Hall Regents.

Çakir, I. (2006). Developing cultural awareness in foreign language teaching. Turkish Online Journal of Distance Education, 7(3), Article 12, 154-161.

Chastain, K. (1988). Developing second-language skills. the USA: HBJ publishers.

Hiep, H. H. (2007). Communicative language teaching: Unity within diversity. English Language Teaching Journal, 61(3), 193-201.

Littlewood, W. (2001). Students' attitudes to classroom English learning: A cross-cultural study. Language Teaching Research, 5(1), 3-28.

Mahmoud, M. M. A. (2013). Islamic Arabic culture in English language textbooks. Saarbrücken, Germany: Lambert Academic.

Mahmoud, M. M. A. (2015). Culture and English language teaching in the Arab world adult learning. Adult Learning, 26(2), 66-72.

Matthew, L. (2012). Promoting respect for cultural diversity in the classroom. Retrieved from http://www.huffingtonpost.com/ matthew-lynch-edd/promoting-respect-for-cul_b_1187683.html

Rivers, W. M. (1981). Teaching-Foreign language skills (pp. 323-324). Chicago, USA: The University of Chicago Press.

Seelye, H. H. (1968). Analysis and teaching of the cross-cultural context. In E. M. Birkmair (Ed.), The Britanica Review of Foreign Language Education, 1(77), 37-81.

Tang, R. (1999). The place of "culture” in the foreign language classroom: A reflection. The Internet TESL Journal, 5(8). Retrieved from http://iteslj.org/Articles/Tang-Culture.html

Wojcicki, E. (2002). Characteristics of an effective classroom culture. Retrieved from http://gallery.carnegiefoundation.org/ collections/castl_k12/ewojcicki2/outcomes/characteristics_culture.htm 